\title{
THE IMPACT OF THE 2013 RULE CHANGES ON GRIPPING CONFIGURATION IN HIGH-LEVEL JUDO ATHLETES
}

\author{
Nemanja STANKOVIĆ ${ }^{1}$, Nikola MILOŠEVIĆ ${ }^{1}$, Mladen ŽIVKOVIĆ ${ }^{1}$ \\ ${ }^{1}$ University of Niš, Faculty of Sport and Physical Education, Niš, Serbia \\ Corresponding Author: \\ Nemanja STANKOVIĆ \\ University of Niš, Faculty of Sport and Physical Education, \\ Čarnojevićeva 10a, 18000 Niš, Serbia \\ Phone: +381691829073 \\ E-mail: nemanjastankovic84@hotmail.com \\ ORCID ID: https://orcid.org/0000-0001-5723-1481
}

\section{ABSTRACT}

PURPOSE: International Judo Federation introduced a set of new rules in a short time period (2009 - 2013). The aim of this research is to determine how the rule modification influences the gripping configurations used by elite male judo athletes.

METHODS: The sample contained 280 combats from the 2011 and 2014 World Championships. All the effective and ineffective throw attempts with related gripping configurations were registered.

The Chi-square test was used to determine the difference between frequencies, along with Z-test for calculating the partial difference.

RESULTS: A total of 1707 actions and gripping configurations were registered. The Chi-square test showed that there is a significant difference in the usage of gripping configurations between the two championships $(\chi 2=32,8$; sig<0,001). The Z-test showed a significant increase in the usage of kenka-yotsu and ai-yotsu, and a significant decrease in the usage of central grip, cross grip and situations where only tori has established a grip. The difference in the usage of the same side grip was not detected.

CONCLUSION: The recommendation for coaches is to reduce the use of all other gripping configurations except kenka-yotsu and ai-yotsu when practicing techniques, especially unorthodox gripping like the cross grip and the same side grip.

Keywords: kumikata, technical-tactical analysis, performance analysis, combat sports 
Nemanja STANKOVIĆ, Nikola MILOŠEVIĆ, Mladen ŽIVKOVIĆ: THE IMPACT OF THE 2013 RULE CHANGES ON GRIPPING ..., 3-13

\section{VPLIV LETA 2013 UVEDENIH SPREMEMB PRAVIL NA IZVAJANJE TEHNIK PRIJEMA PRI VRHUNSKIH MOŠKIH JUDOISTIH}

\section{IZVLE $\check{C} E K$}

CILJ: Mednarodna judo federacija (IJF) je v sorazmerno kratkem obdobju med leti 2009 in 2013 uvedla vrsto novih pravil. Cilj te raziskave je ugotoviti, kako so te spremembe vplivale na izvajanja tehnik prijema pri vrhunskih moških judoistih.

METODE: V raziskavo je bilo vključenih 280 borb iz svetovnih prvenstev $v$ letih 2011 in 2014 in registrirani so bili vsi uspešno, kot tudi neuspešno zaključeni prijemi.

$H i-k v a d r a t$ test je bil uporabljen za ugotavljanje razlik $v$ porazdelitvi frekvenc in Z-test za izračun razlik.

REZULTATI: Skupno je bilo registriranih 1707 akcij in tehnik prijema. Hi-kvadrat test je pokazal, da obstaja pri izvajanju tehnik prijema med obema prvenstvoma pomembna razlika $\left(\chi^{2}=32,8\right.$; sig<0,001). Rezultati Z-testa so pokazali, da je prišlo do povečanja frekvence uporabe prijemov kenka-yotsu in ai-yotsu, in značilno zmanjšanje frekvenc uporabe sredinskega prijema, nasprotnega (križnega) prijema in akcij, kjer je prijem izvedel le izvajalec prijema. Ni bilo razlik med uporabo levega in desnega prijema.

ZAKLJUČEK: Rezultati raziskave navajajo priporočilo trenerjem, da se pri treningu tehnike prijema čim manj poslužujejo vseh konfiguracij prijema razen kenka-yotsu in ai-yotsu. Še zlasti to velja za neortodoksne vrste prijemov, kot so nasprotni prijem in levi oz. desni prijem.

Ključne besede: kumi kata, tehnično-taktična analiza, izvedbena analiza, borilni športi

\section{INTRODUCTION}

A continuous search for improvement made a significant change in judo rules in the last decade. Aiming to promote more attacking style and improve audience understanding of the fight, International Judo Federation introduced a set of new rules in a short time period (Boguszewski, 2011; Franchini, Takito, \& Calmet, 2013; Ito et al., 2013; Calmet, Pierantozzi, Sterkowicz, Challis, \& Franchini, 2017). Including blue and white judogi, excluding the smallest point koka, adding and changing the rules of the fight in the situation of an equal score at the end of the regular time of the fight - it was all a prelude to the most significant rule change in the history of the sport. In 2009, IJF limited direct contact of the attacker's hand below the belt of the opponent (allowed only in counter-attack or as a second part of the combination of techniques). First in 2013, all techniques that include leg grab were completely banned (Franchini, Takito $\&$ Calmet, 2013). This is highly important because the execution of some of the most 
efficient techniques (te guruma, kata guruma, kuchiki taoshi, morote gari) include grabbing the leg of the opponent (Miarka, Ferreira Julio, Del Vecchio, Calmet, \& Franchini, 2010). Secondly, they reduced the importance of penalties in favor of attacking scores. Thirdly, kumikata fighting (grip fighting) was totally altered by forbidding the competitors to break grip with both hands simultaneously. Also, they demand from the judokas to attack "immediately" in the situations where they are having any other grip that is different from the classic judo grip. For both of the above-mentioned infringements, judokas will be penalized with shido (International Judo Federation - IJF, 2013).

These are sport-changing modifications since grip fighting phase makes up a large part of the total combat time (Barreto et al., 2019) and having a dominant grip is one of the most important factors for the positive outcome of the combat (Kajmovic, Rađo, Mekic, Crnogorac \& Colakhodzic, 2014). The players who are able to establish their grip during the fight have more chances to apply their throwing technique or to enforce a penalty to their opponent by making them passive. Grip fighting is also an important factor that distinguishes elite judokas from average and it is documented that it is different in relation to sex, age, weight and judokas' proficiency (Calmet, Miarka \& Franchini, 2010; Miarka et al., 2012, Miarka et al., 2014; Miarka, Sterkowicz-Przybycien \& Fukuda, 2017; Barreto et al., 2019; Dal Bello, Aedo-Muñoz, Brito, \& Miarka, 2019). IJF assumed that changing the kumikata rules will shorten the grip fight and force the judokas to spend more time in firm contact, which is necessary to perform a throw.

Influence of the rule modifications was investigated in the terms of scores and penalties, match duration and the efficiency of judo techniques (Adam et al., 2012; Franchini, Takito \& Calmet, 2013; Calmet et al., 2017; Calmet, Pierantozzi, Sterkowicz, Takito, $\&$ Franchini, 2017). There is scarce evidence about the impact made to gripping strategy used in combat. Therefore, the aim of this research is to determine how the rule modification influences the gripping configurations used by elite male judo athletes. We hypothesised that the rule modification will influence gripping configurations in elite male judo athletes.

\section{METHODS}

\section{Sample}

The sample contained 280 fights from two World Championships (2011 Paris World Championships and 2014 Chelyabinsk World Championships). To ensure the elite characteristic of the sample, preliminary rounds of the tournament were excluded. Final, bronze medal matches, semi-finals, repechages, $1 / 4$ and $1 / 8$ finals from each of the seven men weight divisions were analyzed. For a more detailed analysis, the categories were classified as light (-60kg and $-66 \mathrm{~kg})$, middle $(73 \mathrm{~kg},-81 \mathrm{~kg}$ and $-90 \mathrm{~kg})$ and heavy $(-100 \mathrm{~kg}$ and $+100 \mathrm{~kg})$ according to a previous classification made elsewhere (EscobarMolina, Courel, Franchini, Femia, \& Stankovic, 2014; Stankovic, Cuk, Milosevic, \& Stamenkovic, 2015). 


\section{Variable Data}

Effective actions that ended with a score announced by the referee and ineffective actions in which a contestant clearly unbalanced his adversary were included in the analysis. The observers' task was to associate the appropriate grip configuration with every action that was registered. Gripping variables were as follows: a) ai-yotsu (both athletes used the same grip - right or left); b) central grip (both athletes were gripping the sleeves or lapels at the same time); c) same side grip (the athlete attacking was using a classic lapel grip, but instead of holding the opposite sleeve, he was holding the sleeve on the same side of lapel grip); d) kenka-yotsu (each athlete was holding the opposite grip compared to the opponents grip (i.e., right versus left)); e) cross grip (the athlete attacking was having a classic sleeve grip, but instead of holding opposite lapel, he was holding the lapel on the same side of sleeve grip) and f) only one athlete (tori) was having a grip (the athlete attacking performed the grip and applied the technique before the opponent establishes his grip) (Courel, Franchini, Femia, Stankovic, \& Escobar-Molina, 2014; Stankovic et al., 2015). These grip configurations take into consideration the interaction between the fighters, instead of analyzing only the fighter who is performing the throw attempt. The ai-yotsu and kenka-yotsu grip explain clearly the relations between the judokas. Cross grip, same side grip, and central grip are unorthodox gripping configurations that favor one of the athletes and the referee is obliged to stop the fight and award a penalty to an athlete that was holding this kind of grip for more than five seconds without initiating an attack. There were also situations where the attack was initiated before the opponent was able to establish his grip.

\section{Procedures}

All videos included were provided by the International Judo Federation via their official Dartfish.tv - Channel. Landscape view of the entire competition area and video quality (standard definition 480/60i) provided the necessary ecological validity of the sample. The free computer version of Lince 1.2.1 software, flexible digital recording software that enables data exportation, was used to collect data (Gabin, Camerino, Anguera \& Castañer, 2012).

\section{Reliability Testing}

Two experts with more than 25 years of judo experience, at least $4^{\text {th }}$ Dan-degree black belt and $\mathrm{PhD}$ in Sports Science conducted the analysis. The reliability measures were assessed through intra-observer and inter-observer testing procedures. The following Kappa values and strength of agreement classifications were used: 0.0 to 0.2 , poor; 0.21 to 0.40 , fair; 0.41 to 0.60 , moderate; 0.61 to 0.80 , substantial; 0.81 to 1.00 , almost perfect (Hopkins, 2000). The index and classification of Kappa values for Inter-expert 
(0.74) and Intra-expert (0.88 and 0.91) measurements were classified as "Strong" and "Almost perfect".

\section{Statistical Analysis}

To determine the difference between the two world championships, the Chi-square test at the level of statistical significance of $0,05 \%$ with contingency tables to determine the difference between frequencies was used, along with the Z-test for calculating the partial difference between each variable that was analyzed. Data were analyzed using the IBM SPSS 20.0.

\section{RESULTS}

A total of 280 matches were analyzed, from which 1707 actions were extracted $(6.1$ per match). Number of actions per match increased from 5.4 in 2011 to 6.8 in 2014. The difference in the gripping configurations applied between the two world championships was determined by the $\chi^{2}$ test (Table 1 ). A test result of sig $<0.001$ indicates that there are statistically significant differences in the gripping configurations used.

Table 1. Chi-square test for gripping configurations observed at two championships.

\begin{tabular}{|c|c|c|c|c|c|c|c|}
\hline & $\begin{array}{l}\overrightarrow{0} \\
\frac{0}{0} \\
\frac{1}{2} \\
\frac{1}{4}\end{array}$ & 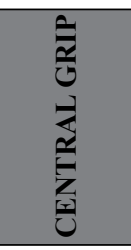 & 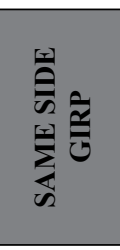 & 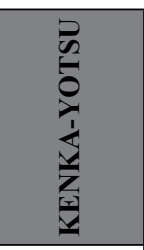 & 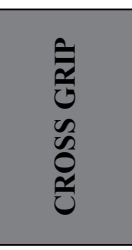 & 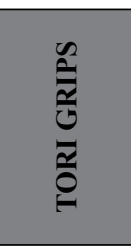 & Total \\
\hline 2011 & $\begin{array}{c}183 \\
(24,11 \%)\end{array}$ & $\begin{array}{c}78 \\
(10,28 \%)\end{array}$ & $\begin{array}{c}37 \\
(4,87 \%)\end{array}$ & $\begin{array}{c}288 \\
(37,94 \%)\end{array}$ & $\begin{array}{c}85 \\
(11,2 \%)\end{array}$ & $\begin{array}{c}88 \\
(11,59 \%)\end{array}$ & 759 \\
\hline 2014 & $\begin{array}{c}257 \\
(27,11 \%)\end{array}$ & $\begin{array}{c}81 \\
(8,54 \%)\end{array}$ & $\begin{array}{c}47 \\
(4,96 \%)\end{array}$ & $\begin{array}{c}436 \\
(45,99 \%)\end{array}$ & $\begin{array}{c}51 \\
(5,38 \%)\end{array}$ & $\begin{array}{c}76 \\
(8,02 \%)\end{array}$ & 948 \\
\hline Total & 440 & 159 & 84 & 724 & 136 & 164 & 1707 \\
\hline \multicolumn{8}{|c|}{$\chi^{2}=32,8 ;$ sig $<0,001$} \\
\hline
\end{tabular}


To determine which gripping configurations contributed to the differences between the two samples, a Z-test was performed for the proportions of the two independent samples. Based on the results obtained, it can be concluded that the ai yotsu and kenka-yotsu configurations were more prevalent in 2014, and the central grip, cross grip and tori grips were more used in 2011.

Table 2. Z-test for gripping configurations observed at two championships.

\begin{tabular}{|l|c|c|c|c|}
\hline & $\mathbf{2 0 1 1}$ & $\mathbf{2 0 1 4}$ & $\mathbf{z}$ & sig \\
\hline AI-YOTSU & $\begin{array}{c}183 \\
(24,11 \%)\end{array}$ & $\begin{array}{c}257 \\
(27,11 \%)\end{array}$ & -2.77 & 0,006 \\
\hline CENTRAL GRIP & $\begin{array}{c}78 \\
(10,28 \%)\end{array}$ & $\begin{array}{c}81 \\
(8,54 \%)\end{array}$ & 4.01 & $<0.001$ \\
\hline SAME SIDE GRIP & $\begin{array}{c}37 \\
(4,87 \%)\end{array}$ & $\begin{array}{c}47 \\
(4,96 \%)\end{array}$ & -0.35 & 0.723 \\
\hline KENKA-YOTSU & $\begin{array}{c}288 \\
(37,94 \%)\end{array}$ & $\begin{array}{c}436 \\
(45,99 \%)\end{array}$ & -5.11 & $<0.001$ \\
\hline CROSS GRIP & $\begin{array}{c}85 \\
(11,2 \%)\end{array}$ & $\begin{array}{c}51 \\
(5,38 \%)\end{array}$ & 15.63 & $<0.001$ \\
\hline TORI GRIPS & $\begin{array}{c}88 \\
(11,59 \%)\end{array}$ & $\begin{array}{c}76 \\
(8,02 \%)\end{array}$ & 8.04 & $<0.001$ \\
\hline
\end{tabular}

By using the $\chi^{2}$ test we found a statistically significant difference when comparing two championships separately by each weight category $(\mathrm{p}<0.05 \%)$. To determine which gripping configurations contributed to the differences between the two samples, the Z-test was performed. In Table 3 the difference between the two championships by weight category was presented. 
Table 3. Z-test for gripping configurations observed at two championships by weight division.

\begin{tabular}{|l|c|c|c|c|}
\hline & & & &
\end{tabular}

$\leftrightarrow$ There is no statistical difference between the two championships; $\uparrow$ there is a statistically significant increase in the usage of kumikata; $\downarrow$ there is a statistically significant decrease in the usage of kumikata.

\section{DISCUSSION}

The aim of the present study is was to determine how the rule modification influences the gripping configurations used by elite male judo athletes. A total of 1707 gripping configurations connected to the throwing attempt were registered in a sample of 280 fights, with 6.1 throwing attempts per match on average. A similar number of fights (242) and throwing attempts (1462) were analyzed in studies conducted by Courel et al. (2014) and Escobar-Molina et al. (2014), noting that their sample consisted of both male and female combats. On average, in these two studies, there was the same number of throw attempts per match (6.0 vs. 6.1). A similar result (7.0) was reported on the sample of International championship matches held during 2011 and 2012, while there were significantly more throwing attempts per combat (9.0) registered at the 2012 Olympics (Miarka et al., 2016). The dominant configurations in both championships 
were kenka yotsu, followed by ai yotsu. While using kenka-yotsu, athletes are typically in an asymmetrical position which increases their chance to score (Mayo, Dopico-Calvo, \& Iglesias-Soler, 2019) while not compromising the defense (Courel et al., 2014). In seniors, the same conclusion was reached by Courel et al. (2014), while in two other studies ai yotsu was the dominant gripping configuration (Kajmovic \& Radjo, 2014; Kajmovic, et al., 2014). A possible explanation is a different sample used in the terms of the level of competition (national vs. elite) and different age categories (cadet vs. senior) when compared to our sample.

As expected, new gripping rules have increased the difficulty of breaking the grip, leading to a significant increase of grip configurations where tori and uke have a strong connection (kenka-yotsu and ai-yotsu). Consequently, a shorter time period judokas spent separated led to a significant decrease in the situations where only one judoka (tori) had a grip. These trends were clearly visible even when the sample was divided by weight category on light, middle and heavyweight.

International Judo Federation wanted to discourage the use of any unorthodox gripping that will give a clear attacking or defensive advantage to one of the contestants. To avoid a potential penalty, they demand from the judokas to attack "immediately" in the situations where they are having any other grip than the classic judo grip. The result is a significant decrease in the usage of cross grip. The decrease is observed in the whole sample, but also when analyzing by weight category. The use of the central grip decreased significantly. Since central grip configuration is a defensive grip, used to block the opponent's attacks rather than to produce our own, the registered decrease can be characterized as a positive outcome of the rule changes.

We hypothesize that the absence of significant differences in the usage of same side grip was due to a modification of one of the most utilized judo techniques - kata guruma (Miarka et al., 2010; Witkowski, Maśliński, \& Kotwica, 2012). The classic kata guruma is performed by grabbing the opponent's leg, which was previously allowed. Now, judokas avoid breaking new rules while applying kata guruma by grabbing the sleeve instead of the leg of the opponent (Ito et al. 2013). The significant increase of the same side grip was observed in light and middleweight categories, while there was a decrease in heavyweight. Kata guruma is rarely used by heavyweights since for executing the technique one needs to hold complete weight of the opponent on the shoulders.

The present results demonstrated the differences in the usage of gripping configurations before and after the rule change. The fact that ai yotsu and kenka yotsu combined for $73 \%$ of all grip configurations used in 2014 (vs. 62\% in 2011) further highlights the importance of the firm connection between the judokas during the execution of the throw. By shortening the allowed time to use unorthodox grips, the usage of these grips during the attacking actions was reduced significantly (from $16 \%$ in 2011 to $10 \%$ in 2014). 


\section{CONCLUSION}

The current research aimed to compare gripping configurations used in two world championships. Summarizing the results it can be stated that the aimed outcomes of the gripping rule modification have been achieved. By making it harder to break the grip of the opponent, judokas were forced to use the gripping configurations that include a firm relationship with their adversary, thus providing more attacking attempts per combat. The recommendation for coaches is to significantly reduce the use of all other gripping configurations when practicing techniques, especially unorthodox gripping like cross grip and same side grip. These findings will help coaches build adequate training regimes in order to improve their competitors' technical and tactical skills that are necessary for competing at the highest level of competition.

\section{REFERENCES}

Adam, M., Tabakov, S., Klimowicz, P., Paczoska, B., Laskowski, R., \& Smaruj, M. (2012). The efficiency of judo techniques in the light of amendments to the rules of a sports contest. Journal of Combat Sports and Martial Arts, 2(2), 115-120. https://doi. org/10.5604/20815735.1047658.

Barreto, L. B. M., Dal Bello, F., Araujo, R. A., Brito, C. J., Fernandes, J. R., \& Miarka, B. (2019). Judo approach and handgrip analysis: determining aspects of world circuit high performance. Journal of Physical Education and Sport, 19(2), 413-419. https://doi. org/10.7752/jpes.2019.s2061.

Boguszewski, D. (2011). Relationships between the rules and the way of struggle applied by top world male judoists. Archives of Budo, 7(1), 27-32. http://archbudo.com/view/ abstract/id/10617.

Calmet, M., Miarka, B., Franchini, E. (2010). Modeling of grasps in judo contests. International Journal of Performance Analysis in Sport, 10(3), 229-240. https://doi.org/10.1 080/24748668.2010.11868518.

Calmet, M., Pierantozzi, E., Sterkowicz, S., Challis, B., \& Franchini, E. (2017). Rule change and Olympic judo scores, penalties and match duration. International Journal of Performance Analysis in Sport, 17(4), 458-465. https://doi.org/10.1080/24748668.201 7.1350489 .

Calmet, M., Pierantozzi, E., Sterkowicz, S., Takito, M. Y., \& Franchini, E. (2017). Judo rules: searching for a wind of changes. International Journal of Performance Analysis in Sport, 17(6), 863-871. https://doi.org/10.1080/24748668.2017.1405612.

Courel, J., Franchini, E., Femia, P., Stankovic, N., \& Escobar-Molina, R. (2014). Effects of kumi-kata grip laterality and throwing side on attack effectiveness and combat result in elite judo athletes. International Journal of Performance Analysis in Sport, 14(1), 138-147. https://doi.org/10.1080/24748668.2014.11868709.

Dal Bello, F., Aedo-Muñoz, E., Brito, C. J., \& Miarka, B. (2019). Performance analysis and probabilities by gender in judo: combat phases, techniques and biomechanical levers. Facta Universitatis, Series: Physical Education and Sport, 17(1), 135-148. https:// doi.org/10.22190/FUPES190415015D. 
Escobar-Molina, R., Courel, J., Franchini, E., Femia, P., \& Stankovic, N. (2014). The impact of penalties on subsequent attack effectiveness and combat outcome among high elite judo competitors. International Journal of Performance Analysis in Sport, 14(3), 946-954. https://doi.org/10.1080/24748668.2014.11868770.

Franchini, E., Takito, M. Y., \& Calmet, M. (2013). European Judo Championships: impact of the new rule changes on points and penalties. International Journal of Performance Analysis in Sport, 13(2), 474-479. https://doi.org/10.1080/24748668.2013.118 68663.

Gabin, B., Camerino, O., Anguera, M. T., \& Castañer, M. (2012). Lince: multiplatform sports analysis software. Procedia Computer Science Technology, 46, 4692 - 4694. https://doi.org/10.1016/j.sbspro.2012.06.320.

Hopkins, W. G. (2000). Measures of reliability in sports medicine and science. Sports Medicine, 30(1), 1-15. https://doi.org/10.2165/00007256-200030010-00001.

International Judo Federation - IJF. Refereeing \& Organization Rules Changes - Explanations. Retrieved from http://www.ijf.org/ (accessed May 3, 2013).

Ito, K., Hirose, N., Nakamura, M., Maekawa, N., Tamura, M., \& Hirotsu, N. (2013). The transformation of technical-tactical behaviors for hand techniques used in attacking below the belt after the 2010 International Judo Federation rule revision. Archives of Budo, 9(1), 1-6. Retrieved from http://archbudo.com/view/abstract/id/10557.

Kajmovic, H., Rađo, I., Mekic, A., Crnogorac, B., \& Colakhodzic, E. (2014). Differences in gripping configurations during the execution of throwing techniques between male and female cadets at the European Judo Championship. Archives of Budo, 10, 141-146. Retrieved from http://archbudo.com/view/abstract/id/10509.

Kajmovic, H., \& Radjo, I. (2014). A comparison of gripping configuration and throwing techniques efficiency index in judo between male and female judoka during Bosnia and Herzegovina senior state championships. International Journal of Performance Analysis in Sport, 14(2), 620-634. https://doi.org/10.1080/24748668.2014.11868747.

Mayo, X., Dopico-Calvo, X., \& Iglesias-Soler, E. (2019). An analysis model for studying the determinants of throwing scoring actions during standing judo. Sports, 7(2), 42, https://doi.org/10.3390/sports7020042.

Miarka, B., Ferreira Julio, U., Boscolo Del Vecchio, F., Calmet, M., \& Franchini, E. (2010). Técnica y táctica en judo: una revisión. Revista de Artes Marciales Asiáticas, 5(1), 91-112. https://doi.org/10.18002/rama.v5i1.139.

Miarka, B., Panissa, V. L. G., Julio, U. F., Del Vecchio, F. B., Calmet, M., \& Franchini, E. (2012). A comparison of time-motion performance between age groups in judo matches. Journal of Sports Sciences, 30(9), 899-905. https://doi.org/10.1080/02640414 .2012 .679675 .

Miarka, B., Cury, R., Julianetti, R., Battazza, R., Julio, U. F., Calmet, M., \& Franchini, E. (2014). A comparison of time-motion and technical-tactical variables between age groups of female judo matches. Journal of Sports Sciences, 32(16), 1529-1538. https:// doi.org/10.1080/02640414.2014.903335.

Miarka, B., Del Vecchio, F. B., Julianetti, R., Cury, R., Camey, S., \& Franchini, E. (2016). Time-motion and tactical analysis of Olympic judo fighters. International Journal of Performance Analysis in Sport, 16(1), 133-142. https://doi.org/10.1080/247486 68.2016.11868876. 
Nemanja STANKOVIĆ, Nikola MILOŠEVIĆ, Mladen ŽIVKOVIĆ: THE IMPACT OF THE 2013 RULE CHANGES ON GRIPPING ..., 3-13

Miarka, B., Sterkowicz-Przybycien, K., \& Fukuda, D. H. (2017). Evaluation of sexspecific movement patterns in judo using probabilistic neural networks. Motor control, 21(4), 390-412. https://doi.org/10.1123/mc.2016-0007.

Stanković, N., Cuk, S., Milosevic, N., \& Stamenkovic, S. (2015). The course of the judo fight at the 2011 World championship. Facta universitatis-series: Physical Education and Sport, 13(1), 107-113. Retrieved from http://casopisi.junis.ni.ac.rs/index.php/FUPhysEdSport/article/view/838.

Witkowski, K., Maśliński, J., \& Kotwica, T. (2012). Analysis of fighting actions of judo competitors on the basis of the men's tournament during the 2008 Olympic Games in Bejing. Journal of Combat Sports and Martial Arts, 2(2), 121-129. https://doi. org/10.5604/20815735.1047659. 